\title{
The ABC's changing role as a provider of education television programs
}

\author{
Grahame Ramsay \\ School of Humanities and Applied Social Sciences \\ Nepean College of Advanced Education
}

\begin{abstract}
The ABC's role as a telecaster of educational programs has undergone fundamental change since it became a corporation. Yet these changes have not attracted the publicity and debate that alterations to the $A B C$ Television's evening schedule have. TV transmission that was once tailored to State needs is now beamed nationally by satellite. Advisory links between the ABC and State Education Departments have been severed. Copyright continues to present problems and the provision of entertainment and education programs for children has been merged under the control of one department. This paper examines the ABC's former role as a producer of educational television programs, looks at the recent policy changes, and suggests some possibilities for the future. It also considers the rise of alternatives to the $A B C$ in education program making and distribution.
\end{abstract}

The provision of educational programs for schools has always been a major component of the Australian Broadcasting Commission's daytime television scheduling. These programs demonstrate a distinctive feature of the $A B C$ as a public service broadcaster and represent an obvious difference from commercial television where daytime offerings have been dominated by chat shows and soap operas. But since the ABC became a Corporation, there have been changes in the structure, philosophy and approach of the $A B C$ to educational programs. The $A B C$ Education Department has been abolished and replaced by a hybrid Department called "Children's and Education (TV)". National satellite transmission has replaced state-based programming. Repeats of evening programs are a 
feature at midday and the number of new education programs produced for schools has dropped. These changes have not occasioned the public discussion which was produced by alterations to the evening schedule. Yet the long-term implications are no less dramatic and crucial to the shape of Australian public service broadcasting.

In January 1987, the $A B C$ launched a new program guide called $A B C$ Daytime. It replaced previous guides to $A B C$ television and radio education programs. The change was more than cosmetic. For the first time programs from "Infants" to "Adult" were included in the one publication. The change meant that education programs were no longer provided to each State at times to suit variations in that State's school holidays. In the past, separate program guides were introduced which reflected those differences between States. In the past some programs, such as Perth's Here in the West, had been designed for transmission in only one State, but now the output of programs has been centralised. This also mirrors the organisational centralism of the new ABC. Educational program making had always been an important function of the B.A.P.H. (Brisbane, Adelaide, Perth, Hobart) States. Television crews in these smaller States could expect to do items for news and current affairs and education. The education programs often provided opportunities for creative work beyond the more routine news tasks. The award-winning educational series Six Australians was produced in Adelaide. Hobart produced a long-running series of science programs called Hunter, Queensland Education produced Northern Australian Documentaries and Perth produced programs in the For the Juniors series. The diversity of locations reflected Australia's geographical diversity. This approach has not been completely abandoned, but the new Children's and Education Department (TV) locates all Executive Producer authority and supervision in Melbourne and Sydney.

These changes have not come about because of any detailed judgment of a need to radically alter education program-making. Some reappraisal of the place of educational television in the $\mathrm{ABC}$ may indeed be necessary, but the radical reoganisation of $A B C$ Education has preceded rather than followed such a review. The Dix Committee (1981) saw no need to combine the operation of the Children's and Education Departments recognising the need for their separate roles within the ABC (Dix, 1981, 11.219).

Thus taking the word "education" out of the Logo ABC Daytime is no mere publicity push, but represents a major shift in the ABC's commitment to education program production, especially programs for schools. This 
development raises basic questions about the appropriate role of the $\mathrm{ABC}$ in providing education programs. The debate has raged within the $A B C$ for some years under different guises. The ABC Education Department has been viewed as a low priority area in terms of resources because it did not offer programs to the adult evening audience. Public discussion of educational television has been limited. Such programs as Playschool have been singled out for praise, but for the most part $A B C$ educational programs have been accepted without comment as part of the $\mathrm{ABC}$ 's output. There is, however, an important national audience for programs. It does not show up as television ratings because it's not an audience watching at home. $\mathrm{ABC}$ surveys have indicated that $\mathrm{ABC}$ education programs are being used by teachers throughout Australia. The popularity of programs varies but the most popular program, according to the latest research, was Behind the News. This was used by more than two thirds of primary teachers in Australia in 1986 and reached an estimated 900,000 primary children. (Palmer \& Black, 1987b, p21). These audiences will be at risk if the quality or quantity of education programs diminishes.

The effect of the reorganisation of ABC Education has been masked by the large number of repeat programs still filling the daytime schedule. As the years go on, the amount of new ABC-produced material will drop to be replaced by overseas programs and dual purpose/co-productions aimed at a nebulous adult/upper secondary audience. This is despite the fact that primary programs have attracted the $\mathrm{ABC}$ 's largest school audiences.

The response of the State Education Departments has been tempered by their own budget restraints. When cutbacks to the $A B C$ education service were mooted in June 1985, the NSW Education Department responded by threatening to reduce its liaison services to the $\mathrm{ABC}$. In practice this threat has become a reality with the reduction nationally of liaison officers seconded from Education to the ABC. The relationship between the ABC and State Education systems is an interesting issue. The Dix Committee, noting that Schools were primarily a State and not a Federal responsibility, recommended that the provision of funds and other forms of support for any major expansion of $\mathrm{ABC}$ education broadcasts should be a matter for negotiations between the $\mathrm{ABC}$ and the appropriate State education authorities (Dix, 1981, 15.164). Senator Evans 1988 discussion retains "Education" as a core charter activity of the $\mathrm{ABC}$ but the service to schools is still at risk with further budget cuts.

The new Corporation Act contained a clause requiring the $\mathrm{ABC}$ to "take account of the responsibilities of the States in relation to education" (ABC Act, 1983, 6: 2). The ABC Corporate Plan (1985) simply avoided the issue, stating that there would be no increase in education or children's programming in the immediate future ( $\mathrm{p} 12)$. 
This paper, as a way of placing recent events into context, will consider the way educational television developed in the ABC. This will involve some clarification of the nature of educational television programs. It also requires the study of the evolution of $\mathrm{ABC}$ Education until the $\mathrm{ABC}$ became a Corporation, and the consideration of the internal reorganisation in recent years.

\section{The nature of education television}

The use of the term "education" and "educational" applied to television programs presents peculiar problems. A common theme that has been found is that a popular view of educational programs is "those programs made for schools" (Bates, 1977, p8). Yet at the International Conference on Education and Research in Educational Television and Radio at the Open University in 1976 there were papers on educational broadcasting for Universities and Colleges as well as schools (Bates, 1977, 1).

The Dix Committee (1981) felt the need to indicate that its use of the term "education", in a chapter on the ABC's educational programs, was "material designed for specific learning purposes rather than material of a generally educative nature" (15 2). This is an important distinction. The rescheduling of programs such as Four Corners and Big Country in daytime viewing and their popularity in schools surveys (Palmer \& Black, 1987a, p20) indicates that general programming can be used for "educational" purposes. This does not negate the need for series designed specifically with a schools audience in mind. The Gilmour Committee (1979) noted the importance of "series" in its definition of educational programs:

Educational broadcasting, is broadcasting with predetermined educational objectives, normally planned in a series, which are designed to lead to the mastery of a body of knowledge (p2).

All these definitions fit the pattern of development of educational series within the ABC until 1984. Since that time structural change and the policy of senior management have led to the production of some programs designed more to meet co-production objectives than educational ones.

It is, however, important to go beyond these definitions to look at the kind of programs produced in the pre-1980 period, "Educational television" conjures up, for some, images of direct teaching by a television lecturer. In fact this approach had not been used by the ABC since 1968 (Dix 
Committee, 1881, 15.8), but old images die hard. When Richard Thomas, then Head of $A B C$ Television, first met a group of educational television producers he told them that "he was not familiar with $\mathrm{ABC}$ education programs but he hoped they did not include any teachers and blackboards" (Meeting of staff, 13th September, 1984). When he was shown innovative drama productions designed as education programs for Mathematics he was delighted. (Author's own experience).

The range of styles in education programs produced by the $\mathrm{ABC}$, before 1980, was broad. Drama was used in structuring programs on subjects such as English, Science, Mathematics and Personal Development. Magazine-style formats were used for educational news, current affairs series and transition education. The subject did not dictate the production style; rather, a style was chosen that would communicate effectively. For instance, the magazine style suits Behind the News which is produced weekly, whereas drama suits series that will have a longer life and are less 'information giving' in their approach.

This explains why educational programs have to be defined by their audience or their objectives-because they do not fit into a neat "genre". Part of the challenge of educational producers is to find the right combination of approaches to a subject. Some Programs include a mixture of all styles. For example, each episode of a language series Passwords included a mock quiz show, commercials, a documentary, a live-eye cross to a comic character, and a dramatised sequence.

Within these definitions there is no reason why the $A B C$ had to limit itself to only Schools programs. The ABC Education Department had recognised this and proposed moving into programs for TAFE colleges and students, as well as continuing/further education audiences. The problem was that any expansion into those areas would need an increased allocation to $A B C$ Education or a decision to reduce its commitment to schools.

However, the emphasis on providing programs to schools was also a legacy of the way the $\mathrm{ABC}$ established and structured its Education Department.

\section{The development of $A B C$ education}

Until 1984 education programs were produced by six state ABC Education Departments and a Federal ABC Education Department. (These are best referred to as $A B C$ Education Departments to avoid confusion with the State Government Departments of Education). The Commission was 
under no obligation to produce education programs, although it did. The Corporation Act likewise produces no obligation but calls on the $\mathrm{ABC}$ to "produce radio and television programs of an educational nature" (ABC Annual Report, 1984, p3). The problems of defining "educational" have already been illuminated.

The relationship between the $\mathrm{ABC}$ and the Education Departments operated by 1984 in three ways. Formally, each State had an advisory committee or consultative committee chaired by the Director General of Education or equivalent and representatives including teachers, nongovernment schools, parents, and in some states TAFE. Secondly, each State Education Department maintained a liaison officer(s) who worked frequently within the $\mathrm{ABC}$ to ensure communication between the $\mathrm{ABC}$ Education Department and the State Education Department. In practice these people did everything from conducting surveys and visiting schools to consulting with producers about scripts. Thirdly, consultation did not mean that the State Education Departments told the $A B C$ what series to make or how to make them. Editorial judgments and production values were determined by $\mathrm{ABC}$ producers. The way producers responded to the perceived needs, as advised by the Departments, was also up to the ABC.

The evolution of educational broadcasting until 1975 has been considered to fall into three periods (Gilmour, 1979). In the first period (1932-1945) educational radio was gradually developed. Reception of programs was hampered because State Education Departments did not commit adequate funds for radio receiving equipment. During the second period (19461964) the State Education authorities provided equipment and television began to make its mark. The third period (1965-1979) can be seen as a boom period. There was an increased use of programs and by the end of this period television was being used more than radio in schools.

To this can be added two more periods. In the fourth (1979-1983) the reduction in funds to the $A B C$ led to a reduction in money available for education programs. In the squeeze for resources Education was hampered by priority given to other Departments. Nevertheless a service to schools was still maintained. The Dix Committee observed that, "on the basis of the programs we saw and heard from the ABC Education Department, we can only say that we believe it performs a remarkable job within these limitations" (Dix, 1981, 15.110).

The advent of the new Corporation provided an opportunity for the $\mathrm{ABC}$ to re-evaluate its commitment to education and moved the $\mathrm{ABC}$ Education Department into a fifth stage. 


\section{The Corporation and education (1983-1987)}

The ABC Education Department was affected by the general purge that occurred within the new Corporation. It was more vulnerable because it was an "integrated" department producing both radio and television programs. The new Corporation was "media split". The radio and television functions in the $\mathrm{ABC}$ were separated. The main production effort of the new Corporation was to be centralised in Sydney and Melbourne.

The Director of ABC Education was among those senior executives who received the "long white envelopes" that told them their positions had been abolished. Education producers hoping for some support from the $\mathrm{ABC}$ Board for the Department were disappointed. In a statement of purpose and organisational goals education was only mentioned obliquely (Annual Report 1984, p5). Meanwhile, plans to implement the media split led to detailed staff consultations. Nationally, recommendations put by the staff were rejected completely by the Managing Director, Geoffrey Whitehead, in November 1984. Ultimately staff were allocated to either radio or television. Many were unhappy and took advantage of voluntary redundancy in May 1985. Sydney lost almost half its Education staff. For those who remained, the budget cuts further hit program making. The Education (TV) Department was told that it would have to forego editors and camera crews to ensure the (short-lived) news program The National would continue unaffected. In program terms Education's output did not fit into the new streaming philosophy of the Corporation. In the now separate "Schools and Continuing Education Radio Department" all secondary radio broadcasts were abolished. As the Corporate plan described it, "programming will be tailored for better integration with National station program sequences" (ABC Corporate Plan, 1985, pl8).

The television education department was settling into its new role by June 1985. Program proposals had been developed and new series were in production. The output of programs was lower than in previous years but the priority was still to provide programs to schools. In June 1985, in the wake of budget cuts by the Federal government, the Television Education Department was dealt the largest cut of all. It was to lose $27 \%$ of its already modest budget. This compared with the cut of $6 \%$ for the News and Current Affairs Department (SMH 21/6/85, p2). In mid-July the ABC senior management added to the crisis caused by these massive cuts by deciding on a surprise move. The $\mathrm{ABC}$ Television Education Department was to be amalgamated with the ABC's TV Children's Department. On the surface the two departments had a common audience-children. However, in other ways the Departments were incompatible. Their approach to 
producing television programs were very different. The skills of their producers differed. The TV Children's Department was a centralised Sydney operation, while Education TV maintained staff and production in the States as well as Sydney.

In August 1985 a meeting of senior staff considered program proposals for the combined Television Department. The obvious differences between the former Department's output and the new one were an increase in plans for dual purpose programs for both education and adult viewing. There was an absolute priority given to programs that included co-production money from outside the $\mathrm{ABC}$. There was also a move towards long-running studio-based format programs and away from shorter, quality drama series with specific educational goals (author's own experience).

Four issues were of particular concern in the new Department. These were centralism, the relationship with State Education Departments and other educational bodies, co-production, and copyright.

\section{(a) Centralism}

Until 1985, the former ABC Education Department received a budget from $A B C$ management. It was then left up to the Department itself to decide how that budget was allocated to programs. This was done by each $A B C$ State Supervisor gathering proposals which were then argued out at a meeting of Supervisors in Sydney. ABC senior management outside the Education Department rarely concerned themselves with the detail of education programs. There were signs of the change in approach with the more centralist management under Geoffrey Whitehead (Managing Director) and Richard Thomas (Head of Television). In June 1985, when the announcement came that the Education Department was to shed 23 hours of proposed programs, senior $\mathrm{ABC}$ management also instructed which series should be cut (SMH 21/6/85, p2). Staff in the ABC Education Department protested. The Acting Head of the Department proposed alternative plans, only to be demoted for his trouble.

The structure of the new Children's and Education Department (TV) (CHED) actually cemented the idea of central control. The positions of State supervisors were abolished and all Executive Producer authority was vested in three Executive Producers in Sydney and one in Melbourne. The Executive Producers each supervised a particular audience age-group that corresponded to pre-school, primary, secondary and adult. Editorial control was shifted away from the States, with the new Executive 
Producers flying around Australia to exercise their control. This has led to some major internal battles over what is an appropriate style for a program and who has editorial control. The State offices now rely on the outcome of discussions in Sydney, whereas in the past they operated more independently.

\section{(b) The relationship with state education departments}

The decline in the provision of education programs since the $\mathrm{ABC}$ became a Corporation has prompted a reaction from State Education Departments. The number of liaison officers seconded to the ABC by the Education Departments has been cut. In NSW and Victoria the number dropped from four to two, while in other States a part-time service is still provided. There are none in the Northern Territory and Western Australia (ABC Daytime, 1987, p9).

The Education Departments have also developed separate audio-visual units which include video production. These serve what are seen as State needs. In 1988 the role of these units has expanded to provide material for telecast on SBS under the general title of SBS TV-Ed. Although the programs go out nationally between $3 \mathrm{pm}$ and $4 \mathrm{pm}$ each weekday each state has specific days for their programs. There are also contributions from Technical and Further Education and the Commonwealth Employment Service. For second term 1988, the daily themes have been Monday-Staff Development, Tuesday-Primary, Wednesday-TAFE, Thursday-Secondary and Friday Careers and Community Education. The reception area for SBS is limited in many areas and in Victoria regional television stations record the programs from the satellite and then rebroadcast them.

The inclusion of primary and secondary programs is an interesting development considering this is the traditional school's television audience provided for by the ABC. Even though its only two hours per week it leaves the way open for an argument that the TV-Ed model might be appropriate to the ABC. The attraction for Governments would be that the cost of programs are being borne by the Education Departments.

However this argument ignores the national character of the ABC. The TVEd project on SBS is using time that SBS has not usually been operating. There have been proposals, a few years ago, that the whole of the ABC's schools programs should be transferred to SBS. But there have not been any recent moves, to my knowledge, along these lines. 
It's too early to judge the success of SBS TV-Ed which only began national transmissions on SBS in February 1988. The project is a loose coalition of State interests. The range of program material from inservice to classroom stimulus material suggests that there are by no means common assumptions among the various education departments about the network.

The Assistant Director of Services, NSW Department of Education, Mr Alan Pratt said "the project still has trial status and the Department has to decide if it can afford to maintain such a service if research shows it a success".

The Q-Net service in Queensland provides another model for distributing programs. It's a combination of Government and private enterprise. The satellite component seems likely to be sold to Bond Media. The network has some seventy earth stations located at either schools or TAFE colleges. The bulk of the material is aimed at TAFE. A well equipped broadcast standard television studio TSN (formerly the School of Electronic Media Studies) acts as the producer for other organisations such as the Department of Health. The Queensland Department of Education makes limited use of the facilities to produce in-service videotapes for teachers. The Operations Manager, Q-Net, Mr Phil Buhot said "the present programming and distribution should remain the same under the privatisation agreement".

Meanwhile, the ABC's connections with State Education Departments have changed. The formal links that existed through State Advisory Committees have ended. These bodies were abolished by the Corporation. Another form of consultation, a special "interest seminar" was conducted in 1986 but has since been abandoned because of cost individual producers still maintain their own links and seek specialist educational advice where appropriate. The end of more formal structures indicates a significant shift away from the cooperative approach of the past. The state education departments face their own budget constraints and the position of those liaison officers still working in the $\mathrm{ABC}$ is tenuous.

\section{(c) Co-production}

One of the realities of the financial squeeze on the $A B C$ and especially CHED (TV) is that co-production money is now essential to keep production going. Any co-production deals that are made immediately get a double "A" rating for facilities from the $\mathrm{ABC}$. For example, a coproduction with the Powerhouse Museum was the major product besides Playschool of the Sydney office of CHED (TV) in 1987. In this and other co- 
production deals the $\mathrm{ABC}$ is becoming more like a production house for outside organisations. A series of co-funded programs on cancer made by the new department included the provision of videos for the Cancer Council. The series PGR, concerning parenting, has been supported by the South Australian Health Department. There are also plans to do programs in association with the Asian Studies Council.

These projects have merits and the questions raised by co-productions are many. Would the series have been a priority for the ABC had it not been for co-production money? What series were cancelled to allow the coproductions to go ahead? Should a "public service broadcaster" be producing videos for outside organisations? These questions are not easily answered because, in some cases the CHED Department would have had to trim staff even more, had it not been for co-production money. There is a danger in the long term that co-production could so dominate the planning of the department that it has little production effort on its own initiative. The Head of the Department argues that priorities have not been skewed and that co-productions with Government Departments seem to have similar priorities to the national priorities of the Education community.

\section{(d) Copyright}

There is agreement between the copyright owners and users that the law should be changed to allow copying, on licence, off air. However, in mid 1988 there are still delays in the Attorney General's Department in changes going through. The provisions of the 1968 Act still apply. They make it illegal to videotape $A B C$ television programs and there is no provision that would allow schools to copy under the existing law. The ABC in its days as a Commission turned a blind eye to copyright and school broadcasts. Headmasters who wrote seeking permission to copy were told that the $\mathrm{ABC}$ held only broadcast rights and that they should take up the issue with their State Education Departments. Education Departments have flouted the law, in the interests of using programs, by providing videocopying services for schools. The $\mathrm{ABC}$ has so far not taken action against Education Departments which contravene the copyright law. The ABC's Principal Legal Officer, Jennifer Harris, said in 1984 that "the ABC has always been liberally extended towards children" (SCAN, February 20-March 4,1984:9). Although the new CHED (TV) Department is now telling callers seeking permission that copying is illegal. Another factor affecting the $\mathrm{ABC}$ is its increased push into marketing. It now produces videocassettes of such programs as Playschool so it has some vested interest in restricting illegal copying. The fear of prosecution, however unlikely, is enough to terrify many audio-visual librarians to ban copying of $\mathrm{ABC}$ programs. 
The Playschool example demonstrates the problems of copyright when producing videos as opposed to productions for broadcast. The producers of Playschool had difficulty in obtaining permission from publishers to dramatise certain children's books because the publishers feared a video cassette would reduce the book sales. Actors, too, negotiate higher fees if they are appearing in a video cassette to be sold through $\mathrm{ABC}$ shops.

In the planned changes to the copyright law is expected that it will be legal for educational institutions to make copies providing they pay a fee for every program recorded off-air. The legislation would cover all television programs whether designed for educational viewing or not. (Film News, March 1987; p 15).

The lack of special concessions for educational programs presents problems for specialist program production. The right to copy has been exercised (if illegally). Now those programs could incur the same fee per hour as an evening program. On the one hand, the proposed law acknowledges the possibility that many television programs can be used in educational settings, but on the other hand (it) may have the unintended result of reducing the use of specialist educational programs. This fear was expressed by the ABC to the Senate Standing Committee on Education and the Arts. (Canberra Times, 6/8/86 ).

There are different problems in the tertiary and secondary sectors. The tertiary sector have agreed in principle to supply details of their copying so any fees can be apportioned. Copyright owners and tertiary institutions have held meetings to talk about possible fees for off air recording. The Copyright Council have yet to have specific discussions with Education Departments where record keeping in schools presents real problems.

A more immediate solution to the copyright problems has been offered by two commercial companies. The Learning Network and Classroom Video provide services that are starting to make an impact on schools and the tertiary sector. The first involves an "off-air recording licence" for specific programs. The second relies on distribution by videotape.

The Learning Network began its service in March 1987, It contracted with the $\mathrm{ABC}$ and $\mathrm{SBS}$ to provide time to broadcast programs over their Networks. Seventeen tertiary institutions have incorporated the courses from the Learning Network into their programs. More than one thousand students are enrolled for the courses involving television telecasts, 
(Learning Network Newsletter, 1988, 2(1), pi). The telecourses that the Learning Network has rights to are mainly produced overseas and include subjects in the Humanities, Sciences, Business, Technical/Trades and Leisure.

Classroom Video began in March 1984 to produce programs distributed entirely on video. It has an extensive nationwide mailing list of schools. Its 1988 catalogue includes programs ranging from Road Safety to Secondary Science. It specifies that its programs may be lent, shared but are not to be copied. They are sold only as packaged videocassettes. Each program is priced at about sixty-five dollars for a twenty-five minute VHS videocassette. Programs are also being used by TAFE colleges and Universities even though they are designed for schools.

The paradox is that ABC is now "competing" with its own CHED (TV) Department by telecasting programs for the tertiary sector. The Learning Network operates independently of the ABC and SBS in terms of curriculum but the ABC does audition all their programs before transmission to ensure that no broadcast guidelines are breached and to check the quality of the programs. The $\mathrm{ABC}$ faces a dilemma in deciding in what ways it should promote or further financially support the Learning Network company which became a non-profit entity in 1988. Will the ABC provide programs in the future for the Network, and who then will pay for them? The status of the Network, if changes in copyright come in, will be interesting to consider. A special case may be made for the Network's programs not to be covered by the new amendment but by their own agreements with tertiary institutions. If so, the way would be open for separate agreements between institutions and the television stations for other programs.

\section{Future directions}

The extension of education television to include adult education, tertiary courses, in-service programs for teachers in addition to the ABC's traditional service for schools provides a greater range of options than have ever existed before. It represents moves into areas that the $A B C$ has considered but felt reluctant to do at the expense of its service to schools. The expansion also indicates a greater acceptance of television as a means of communication. If Education Departments are now prepared to fund such things as inservice material via television are we on the dawn of an expansion with additional impetus for videotape recorders and monitors in schools.

As for the $\mathrm{ABC}$, there have been some signs that the turmoil of the amalgamation of Children's and Education Departments has subsided 
with some guarantee from the $\mathrm{ABC}$ Board of seventy hours of $\mathrm{ABC}$ produced first release material. The Board has, for the moment at least, accepted that "National Daytime Schools Television" should be an interpretation of the $A B C$ 's role in providing programs of an educational nature. The guarantee of a specific target allows the combined CHED department to adjudicate between the conflicting claims of the Education producers who need resources for their programs and the children's program producers who are much more subject to the needs of the $A B C$ network. Children's programs are more open to direct ratings based competition so there could be a strong case made for priority in that area. The Board's guarantee reduces the difficulties in such arguments. Education was also mentioned as one of the core activities of the $A B C$ in the Evans discussion paper on the future shape of the ABC.

There is some chance now of winning back the respect and co-operation of the State Education Departments. The Board's decision indicates that some commitment is necessary if the school's service of the ABC is to continue. The introduction of possibly competing services such as Q-Net, SBS TV-Ed and the Learning Network indicate scope for expansion of education television.

The expansion of commercial videocassette sales such as Classroom Video also demonstrate that some packaging of programs as videocassettes might be appropriate. The Head of CHED, Henrietta Clark, said that the possibility of packaged programs for secondary schools was being explored. She believes that the new developments such as Learning Network, SBS TV-Ed and Q-Net work in a complimentary way to the $\mathrm{ABC}$.

The ultimate irony would be that the $\mathrm{ABC}$ having pioneered and developed programs for schools may find that its role is being usurped by other networks. The current initiatives don't yet fall into that category but the future mix of education television will no doubt depend on the future shape of the ABC and SBS.

Just as crucial to the ABC's future is the resolution of the copyright position of schools. In this regard the Learning Network has an advantage because they have found ways of allowing students and teachers to legally copy programs under licence. Such issues as copyright, the long term effect of co-productions, and the user-pays principle remain unresolved as far as the $A B C$ is concerned. The way these issues are resolved will determine whether $\mathrm{ABC}$ education programs are to survive at all. 


\section{Bibliography}

Australian Broadcasting Corporation (1985). ABC Corporate Plan, 18851988. Sydney: ABC.

Australian Broadcasting Corporation (1985). Achievement in the implementation of Dix, 1983-1985. Sydney: ABC.

Australian Broadcasting Corporation (1985). Australia-wide School Broadcasts Survey. Sydney: ABC Audience Research.

Australian Broadcasting Corporation (1987). ABC Daytime: A Guide to Television and Radio Education Programs. Sydney: ABC.

Australian Government. (1987). Higher Education: A policy discussion paper. Canberra: Australian Government Publishing Service.

Bates, T, and Robinson, J. (eds), (1977). Evaluating Educational Television and Radio. Milton Keynes: Open University Press.

Dix, A, (Chairman) (1981). The ABC in Review. Vol 1-5. Canberra: Australian Government Publishing Service.

Dranov, P., Moore, L. and Hickey, A. (1980). Video in the Eighties. York: Knowledge Industry Publications.

Gilmour, C. (Chairman) (1979). The Role of ABC Educational Broadcasting. Sydney: Federal Education Broadcasts Advisory Committee.

Hunter, R. (ed) (1987). Educational Technology Newsletter. Toowoomba: Darling Downs Institute Press.

Lusted, D. and Drummond, P. (eds) (1885). TV and Schooling. London: British Film Institute.

Moss, R. (1983). Video: The Educational Challenge. London: Croom Helm.

Palmer, P. and Black, D. (1987a). National Survey of Secondary Teachers' Use $A B C$ Schools Television Programs. Sydney: ABC Audience Research.

Palmer, P. and Black, D. (1987b). National Survey of Primary 7 Teachers' Use of ABC Schools Television Programs. Sydney: ABC Audience Research.

Author: Grahame Ramsay is a lecturer in Media and Coordinator of the Media Production Specialisation at Nepean CAE. Previously he worked as a professional journalist, scriptwriter and television education producer/director at the Australian Broadcasting Commission. He has won Australian and overseas awards, including an Asian Broadcasting Union commendation, for his work. He has developed education television programs in the areas of Australian Studies, Drama, Media Studies and English as a Second language.

Please cite as: Ramsay, G. (1988). The ABC's changing role as a provider of education television programs. Australian Journal of Educational Technology, 4(1), 31-45. http: / / www.ascilite.org.au/ajet/ajet4/ ramsay.html 